\title{
PRESENCE OF DIAMINOPIMELIC ACID IN PROPIONATE-NEGATIVE BACTEROIDES SPECIES AND IN SOME BUTYRIC ACID-PRODUCING STRAINS
}

\author{
R. HAMMANN AND H. WERNER \\ Institute of Medical Microbiology and Immunology, University of Bonn, D-5300 Bonn 1, \\ West Germany
}

\begin{abstract}
SummarY. The presence of diaminopimelic acid (m-DAP) in strains of Bacteroides melaninogenicus, B. bivius and other species as well as in unidentified strains of Bacteroides was investigated by thin-layer chromatography. Strains of $B$. bivius and $B$. disiens all contained m-DAP as did the subspecies intermedius and melaninogenicus of $B$. melaninogenicus. Strains of $\boldsymbol{B}$. asaccharolyticus and similar black pigment-producing butyrate-positive isolates showed heterogeneity. Asaccharolytic strains were DAP negative, whereas two strains fermenting glucose were positive. Some of the non-pigmented propionate-negative and butyrate-negative unidentified strains also contained DAP. The consistent finding of m-DAP in strains of B. bivius, B. disiens, and B. melaninogenicus indicates that DAP detection might be of value in the identification of these species.
\end{abstract}

\section{INTRODUCTION}

Weakly saccharolytic, pigmented and non-pigmented and asaccharolytic pigmented bacteroides strains have been isolated as normal constituents of the oral, vaginal, and urethral flora (Loesche, Socransky and Gibbons, 1964; Hurley et al., 1974; Werner, 1977; Holbrook, Ogston and Ross, 1978; Marrie, Harding and Ronald, 1978; Russell and Melville, 1978; Duerden, 1980). Involvement of these organisms in periodontitis, vaginitis, urethritis, and several other infections has been discussed by several study groups (Loesche, 1980; Sundqvist, 1976; Hammann and Werner, 1980; Takazoe, Tanaka and Homma, 1971; Werner et al., 1979; Socransky and Gibbons, 1965).

In 1964, Loesche et al . described the species Bacteroides oralis as propionate-negative, saccharolytic, non-pigmented, non-sporing anaerobic gram-negative rods, but their strains have been lost. The only extant collection strain of $B$. oralis, AICC15930, has been shown to produce black pigment (Holbrook and Duerden, 1974). However, B. melaninogenicus and B. asaccharolyticus are at present recognised as the taxa comprising black pigmented bacteroides (Finegold and Barnes, 1977; Holdeman, Cato and Moore, 1977). B. bivius and B. disiens described by Holdeman and Johnson (1977) include non-pigmented strains that are weak acid producers.

Cell-wall constituents such as diaminopimelic acid (DAP) have been used for

Received 18 Sep. 1980; accepted 22 Sep. 1980 
taxonomic purposes in the classification of many gram-positive bacteria (Becker et al., 1964; Schleifer and Kandler, 1972; Kroppenstedt and Kutzner, 1976). Williams and coworkers (1975) reported the presence of m-DAP in the cell wall of Bacteroides melaninogenicus ssp. intermedius. These authors did not find $\mathrm{m}-\mathrm{DAP}$ in $B$. melaninogenicus ssp. melaninogenicus or $B$. melaninogenicus ssp. asaccharolyticus (now $B$. asaccharolyticus), but only one strain of $B$. melaninogenicus ssp melaninogenicus was included in their study. In 1976, Shah et al. tested numerous strains of B. melaninogenicus ssp. melaninogenicus for the presence of DAP and found two groups, one with lysine and one with DAP, whereas strains of the subspecies intermedius were all DAP positive and strains of $B$. asaccharolyticus were always negative.

The present paper is concerned with a study of DAP detection in bacteroides strains of several species not belonging to the $B$. fragilis group, with special reference to the taxonomy of the genus Bacteroides.

\section{MATERIALS AND METHODS}

Test strains. The origin of the strains, most of which were clinical isolates, is shown in table I. Strain M95 isolated from the protozoon Paramecium caudatum was supplied by Dr Carmen Martínez Medina, Servicio de Análisis Clínicos, Hospital Provincial, Valencia, Spain. Strain M88 is an isolate from the sewage plant of a village near Bonn; it was isolated from sewage sludge by the same methods as described below for the clinical isolates. The type strains of $B$. bivius (ATCC29303), B. disiens (ATCC29426), B. melaninogenicus ssp. levii (VPI3300), as well as the neotype strains (Cato, Holdeman and Moore, 1979) of B. capillosus (ATCC29799), B. praeacutus (ATCC25539), and B. furcosus (ATCC25662) were kindly provided by Dr L. V. Holdeman, Virginia Polytechnic Institute and State University, Blacksburg, Virginia, USA, and were included for reference purposes.

Culture. The strains were grown on peptone yeast-extract glucose sheep-blood agar or on Schaedler agar containing kanamycin $75 \mu \mathrm{g} / \mathrm{ml}$ and vancomycin $7.5 \mu \mathrm{g} / \mathrm{ml}$ and $8 \%$ of sheep blood. The plates were incubated in GasPak jars (BBL) for at least 3 days at $37^{\circ} \mathrm{C}$. The strains were identified by physiological tests and gas chromatography of the acid end-products. The methods have been described in detail by Werner and Rintelen (1968), Werner (1972) and Hammann and Werner (1980). The strains were kept in Rosenow broth tubes under oxygenfree $\mathrm{CO}_{2}$ and were capped with black rubber stoppers.

Cell-wall analysis for DAP. Strains were grown in 100-ml flasks containing $90 \mathrm{ml}$ of peptone yeast-extract glucose medium, heavily inoculated with Rosenow culture. As soon as sufficient growth was apparent, usually after 2 days, cells were harvested by centrifugation and washed twice with distilled water. Appropriate controls for purity of cultures were done in the usual manner. One $100-\mathrm{ml}$ flask yielded $1 \cdot 5-2.0 \mathrm{~g}$ wet weight of cell deposit which was directly used for the following analysis. Cells were disrupted by ultrasonic treatment (MSE sonicator) for 5-10 min at maximum amplitude. After this time, 80-100\% of the cells were disrupted as shown by gram-stained smears of some of the cultures. The sonicated cell walls were centrifuged at about $5000 \mathrm{~g}$ for $30 \mathrm{~min}$; the supernate was discarded and cell fragments were incubated overnight at $37^{\circ} \mathrm{C}$ with pepsin $(1 \mathrm{mg} / \mathrm{ml}$ in $0.02 \mathrm{~N} \mathrm{HCl}$, containing streptomycin $0.1 \mathrm{mg} / \mathrm{ml}$ to prevent bacterial growth). The incubated cell-wall fragments were centrifuged, washed with distilled water and centrifuged again. They were hydrolysed with $6 \mathrm{~N} \mathrm{HCl}$ at $100^{\circ} \mathrm{C}$ for $16 \mathrm{~h}$ in sealed screw-capped tubes. The hydrolysate was filtered through Schleicher and Schüll paper (No. 595) and dried by evaporation. The dried brownish residues were resuspended in $0.2 \mathrm{ml}$ of distilled water and 5-8 $\mu \mathrm{L}$ amounts were applied to cellulose thin-layer plates (Merck No. 5716). The plates were developed in methanol:distilled $\mathrm{H}_{2} \mathrm{O}: 10 \mathrm{~N} \mathrm{HCl}$ :pyridine $(80: 17 \cdot 5: 2 \cdot 5: 10)$ and sprayed with ninhydrin. DL-DAP (Serva, Heidelberg), L-lysine (Merck), and LL-DAP from whole-cell hydrolysates of Streptomyces griseus or Propionibacterium acnes were included as standards. DAP was detected by its greenish coloration, turning yellow after 1 day, and by comparison of the $R_{\mathrm{f}}$-values. All strains were analysed twice at different times. 
TABLE I

Origin of strains of bacteroides

\begin{tabular}{|c|c|c|c|c|}
\hline Species and strain & n no. & Source & Species and strain no. & Source \\
\hline $\begin{array}{l}\text { B. bivius } \\
\text { B. disiens } \\
\text { Bacteroides spp. }\end{array}$ & $\begin{array}{l}\text { M21 } \\
\text { M22 } \\
\text { M23 } \\
\text { M24 } \\
\text { M25 } \\
\text { M26 } \\
\text { M28 } \\
\text { M35 } \\
\text { M36 } \\
\text { M41 } \\
\text { M43 } \\
\text { M44 } \\
\text { M45 } \\
\text { M56 } \\
\text { M57 } \\
\text { M58 } \\
\text { M74 } \\
\text { M79 } \\
\text { M80 } \\
\text { M86 } \\
\text { M87 } \\
\text { M91 } \\
\text { ATCC29303 } \\
\text { M27 } \\
\text { M38 } \\
\text { ATCC29426 } \\
\text { M4 } \\
\text { M42 } \\
\text { M46 } \\
\text { M52 } \\
\text { M53 } \\
\text { M67 } \\
\text { M68 } \\
\text { M75 } \\
\text { M85 } \\
\text { M88 } \\
\text { M93 } \\
\text { M104 } \\
\text { ATCC29799 } \\
\text { ATCC25539 } \\
\text { ATCC25662 }\end{array}$ & $\begin{array}{l}\text { Vaginal swab } \\
\text { Vaginal swab } \\
\text { Ear of newborn infant } \\
\text { Skin of newborn infant } \\
\text { Vaginal swab } \\
\text { Skin of newborn infant } \\
\text { Vaginal swab } \\
\text { Vaginal swab } \\
\text { Vaginal swab } \\
\text { Vaginal swab } \\
\text { Vaginal swab } \\
\text { Cervical swab } \\
\text { Vaginal swab } \\
\text { Throat, cancer patient } \\
\text { Throat, cancer patient } \\
\text { Throat, cancer patient } \\
\text { Vaginal swab } \\
\text { Vagina, leukorrhoea } \\
\text { Human (unknown) } \\
\text { Vaginal swab } \\
\text { Seminal fluid } \\
\text { Ear of newborn infant } \\
\text { VPI } \\
\text { Operation wound, gynaecology } \\
\text { Vaginal swab } \\
\text { VPI } \\
\text { Vaginal swab } \\
\text { Oral mucosa, normal flora } \\
\text { Vaginal swab } \\
\text { Oral mucosa, cancer patient } \\
\text { Oral mucosa, cancer patient } \\
\text { Prepuce } \\
\text { Abdominal drain } \\
\text { Pus, ear abscess } \\
\text { Vaginal swab } \\
\text { Sewage sludge } \\
\text { Pus } \\
\text { Abdominal drain } \\
\text { VPI } \\
\text { VPI } \\
\text { VPI }\end{array}$ & $\begin{array}{l}\text { B. melaninogenicus } \\
\text { ssp. melaninogenicus } \\
\text { M6 } \\
\text { M47 } \\
\text { M48 } \\
\text { M51 } \\
\text { M54 } \\
\text { B. melaninogenicus } \\
\text { ssp. melaninogenicus } \\
\text { M55 } \\
\text { M59 } \\
\text { M81 } \\
\text { M83 } \\
\text { M95 } \\
\text { M. melaninogenicus } \\
\text { ssp. intermedius } \\
\text { M3 } \\
\text { M17 } \\
\text { M27 } \\
\text { M34 } \\
\text { M63 } \\
\text { M64 } \\
\text { M65 } \\
\text { M76 } \\
\text { M78 } \\
\text { B. melaninogenicus } \\
\text { ssp. levii } \\
\text { VPI3300 } \\
\text { B. asaccharolyticus } \\
\text { and related strains } \\
\text { M2 } \\
\text { M7 } \\
\text { NCTC 9337 } \\
\text { M14 } \\
\text { M16 } \\
\text { M18 } \\
\text { M29 } \\
\text { M62 } \\
\text { M72 } \\
\text { M73 }\end{array}$ & $\begin{array}{l}\text { Oral mucosa, cancer patient } \\
\text { Oral mucosa, normal flora } \\
\text { Oral mucosa, normal flora } \\
\text { Oral mucosa, normal flora } \\
\text { Isolate from Paramecium } \\
\\
\text { Vaginal swab } \\
\text { Bartholinitis } \\
\text { Operation wound, gynaecology } \\
\text { Oral mucosa, normal flora } \\
\text { Oral mucosa, normal flora } \\
\text { Oral mucosa, normal flora } \\
\text { Vaginal swab } \\
\text { Tracheal secretions } \\
\text { Oral mucosa, normal flora }\end{array}$ \\
\hline
\end{tabular}

VPI = strain obtained from Dr L. V. Holdeman, Virginia Polytechnic Institute, Blacksburg, Virginia, USA 


\section{RESULTS}

The results of the DAP thin-layer chromatography study of the strains are shown in table II. The 22 strains previously identified as Bacteroides bivius and the type strain of this species, ATCC29303, as well as two isolates of Bacteroides disiens and the type strain of this species, ATCC29426, contained m-DAP in their peptidoglycan. All strains of B. melaninogenicus tested, no matter which subspecies they belonged to, were positive for m-DAP. In some strains of B. melaninogenicus ssp. melaninogenicus, the m-DAP was difficult to detect and the samples had to be concentrated before clearly visible spots could be found.

The black pigmented, butyric and propionic acid-positive strains of $B$.

TABLE II

Presence of diaminopimelic acid in the strains tested

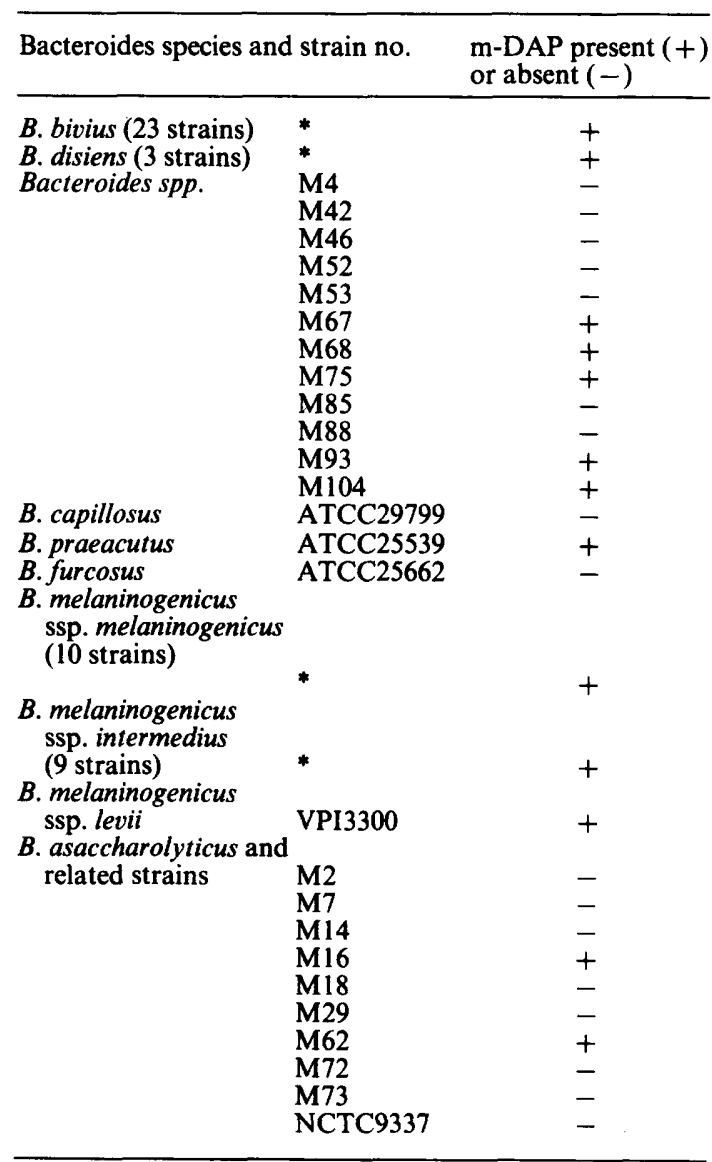

* See table I for strain numbers. 
asaccharolyticus and the butyric and propionic acid-forming strains fermenting glucose as the only carbohydrate, and the type strain of B. melaninogenicus spp. levii, showed some heterogeneity. Besides differences in DAP content, the strains differed in their fermentative abilities towards glucose, lactose, and galactose; B. melaninogenicus ssp. levii fermented glucose, lactose, and galactose weakly. Some of the butyrate-positive, black pigmented strains fermented glucose, whereas others did not; 26 other carbohydrates tested were not affected. In table III the fermentation results are compared with the DAP content of the cell walls. As can be seen, several groups were found. The first group (five strains) consisted of DAP-negative, glucose-positive strains; the second (three strains) neither contained DAP nor fermented glucose or any other carbohydrate tested $(=B$. asaccharolyticus sensu strictiore $)$ and the third (two strains) contained DAP and fermented glucose. B. melaninogenicus spp levii was found to contain DAP.

Some of the non-pigmented strains that could not be assigned to any of the species B. bivius, B. disiens, B. melaninogenicus, or B. asaccharolyticus, showed a positive DAP reaction whilst others did not, according to their different physiological abilities. Some of them (strains M42, M46, M52, M53 and M67) resembled B. oralis; others (M4, M68, M75, M85, M88, M93 and M104) showed some physiological similarities with $B$. capillosus. Most of the strains resembling $B$. oralis did not contain DAP, whereas most of the strains conforming to the physiological description of $B$. capillosus were positive. In the neotype strain of $B$. capillosus and $B$. furcosus DAP could not be detected. $B$. praeacutus ATCC 25539 had m-DAP in its peptidoglycan, but none of the aforementioned strains showed physiological similarities with $B$. praeacutus.

TABLE III

Some differences between B. melaninogenicus ssp. levii, B. asaccharolyticus, and related strains*

\begin{tabular}{|c|c|c|c|c|}
\hline \multirow{2}{*}{ Species and strain no. } & \multirow{2}{*}{$\begin{array}{c}\text { DAP } \\
\text { present }(+) \\
\text { or absent }(-)\end{array}$} & \multicolumn{3}{|c|}{$p \mathrm{H}$ valuet $\underset{\text { with }}{\text { recorded in tests }}$} \\
\hline & & glucose & galactose & lactose \\
\hline $\begin{array}{c}\text { B. melaninogenicus ssp. levii } \\
\text { VPI3300 }\end{array}$ & + & $5 \cdot 9$ & $5 \cdot 8-6 \cdot 0$ & 5.9 \\
\hline B. asaccharolyticus & & & & \\
\hline $\begin{array}{l}\text { M7 } \\
\text { M72 }\end{array}$ & $=$ & 二 & $\overline{-}$ & 二 \\
\hline $\begin{array}{l}\text { M/2 } \\
\text { NCTC } 9337\end{array}$ & - & - & - & - \\
\hline Related strains $\mathrm{M} 2$ & - & $5 \cdot 4$ & - & - \\
\hline M14 & - & $5 \cdot 8-5 \cdot 9$ & 一 & - \\
\hline M16 & + & $5 \cdot 3$ & - & - \\
\hline M18 & - & $5 \cdot 0$ & - & - \\
\hline M29 & - & 5.9 & - & - \\
\hline $\begin{array}{l}\text { M62 } \\
\text { M73 }\end{array}$ & + & $5 \cdot 5-5 \cdot 6$ & - & $\bar{z}$ \\
\hline M73 & - & $5 \cdot 9$ & - & \\
\hline
\end{tabular}

* All strains produced acetic, propionic, isobutyric, butyric and isovaleric acids; small amounts of lactic and succinic acids were also detected. The strains were more or less brown or black pigmented.

$\dagger p \mathrm{H}$ values $\leqslant 6 \cdot 2-7 \cdot 0$ are recorded as - . 


\section{DisCUSSION}

The results show that DAP as a cross-linking amino acid of the peptidoglycan is not limited to various gram-positive bacteria such as clostridia, Eubacterium spp. or aerobic actinomycetes, but may be also a constituent of many anaerobic gram-negative bacilli. This has already been demonstrated by Williams $e$ t al. (1975) and Shah et al. (1976) for some of the black pigmented bacteroides species. The occurrence of m-DAP in the species $B$. bivius, $B$. disiens and other vaginal and oral isolates of the genus Bacteroides has, to our knowledge, not previously been recorded. The inclusion of strains of the same species isolated from different ecosystems (e.g., B. melaninogenicus from human sources and from Paramecium) or from different sites of the human body was meant to test the consistency of certain biochemical markers within a well defined species and, on the other hand, to detect differences within a "bad" species. The presence of $\mathrm{m}$-DAP in all 23 strains of $B$. bivius and three strains of $B$. disiens possibly provides a new reliable basis for identification. Strains of non-pigmented propionate-negative bacteroides isolates not containing $\mathrm{m}$-DAP should probably be assigned to other species. This holds true for our strains M42, M46, M52, and M53 which are very similar to B. oralis. They should, however, not be assigned to this species until a valid neotype strain of this species is available (Shah and Hardie, 1979). The proper taxonomic assignment of the remaining unspecified strains must await future studies.

The black pigmented, butyrate-negative strains of $B$. melaninogenicus all contained DAP. DAP-negative strains of B. melaninogenicus ssp. melaninogenicus were not observed in our studies but, as was reported above, we had some difficulty in detecting the amino acid in some strains of this subspecies, e.g., strain M81. According to Shah et al. (1976), within B. melaninogenicus spp. melaninogenicus there exist strains with lysine in their peptidoglycan. The differences that can be demonstrated among butyrate-positive, black pigmented strains in relation to DAP content and glucose fermentation reflect the non-homogeneity of this group, which was also demonstrated by van Steenbergen, de Soet and de Graaf (1979). It is obvious from the species description (Finegold and Barnes, 1977; Holdeman et al., 1977) that only those of our strains that do not ferment glucose should be assigned to B. asaccharolyticus. The three non-fermenters of glucose that we encountered did not contain DAP and this is in accordance with the results of Shah et al. (1976). The assignation of the glucose-fermenting, black pigmented, butyrate-positive strains to their proper taxon now awaits further studies.

Recently, Mansheim and Coleman (1980) showed that even oral and non-oral strains of $B$. asaccharolyticus are serologically different, have different membrane structures, and have different sugars in their surface layers. According to Slots and Genco (1980) the newly described subspecies macacae of B. melaninogenicus consists of black pigmented strains that ferment glucose, galactose, lactose and mannose weakly, produce acetic, propionic, $i$-butyric, butyric, $i$-valeric and succinic acids. Biochemically, they are very similar to $B$. melaninogenicus spp. levii, which also ferments glucose, galactose and lactose 
and produces the same acids (Holdeman et al., 1977), but ssp. macacae is serologically different from all previously described species and sub-species.

Thin-layer chromatography has proved to be very useful and reliable for the detection of DAP, not only in gram-positive but also in gram-negative bacteria. A review of our own data and those of other groups shows that DAP occurs consistently in strains of $B$. bivius and $B$. disiens. Our DAP-detection studies indicate that $B$. asaccharolyticus, $B$. melaninogenicus and $B$. oralis form a rather heterogeneous group of organisms.

We thank I. Werner and B. Amendt for performing most of the physiological and biochemical tests.

\section{REFERENCES}

Becker, B., Lechevalier, M. P., Gordon, R. E. And Lechevalier, H. A. 1964. Rapid differentiation between Nocardia and Streptomyces by paper chromatography of whole cell hydrolysates. Appl. Microbiol., 12, 421.

Cato, E. P., Holdeman, L. V. AND Moore, W. E. C. 1979. Proposal of neotype strains for seven non-saccharolytic Bacteroides species. Int. J. syst. Bact., 29, 427.

DUERDEN, B. I. 1980. The isolation and identification of Bacteroides spp. from the normal human vaginal flora. J. med. Microbiol., 13, 79.

Finegold, S. M. AND Barnes, E. M. 1977. Report of the ICSB Taxonomic Subcommittee on gram-negative anaerobic rods. Proposal that the saccharolytic and asaccharolytic strains at present classified in the species Bacteroides melaninogenicus (Oliver ad Wherry) be reclassified in two species as Bacteroides melaninogenicus and B. asaccharolyticus. Int. J. syst. Bact., 27, 388.

HAMmANN, R. AND WeRnER, H. 1980. Fermentation products (using g. 1. c.) in the differentiation of non-sporing anaerobic bacteria. In Microbiological classification and identification, edited by M. Goodfellow and R. G. Board, Academic Press, London, p. 257.

HOLBROOK, W. P. AND DUERDEN, B. I. 1974. A comparison of some characteristics of reference strains of Bacteroides oralis with Bacteroides melaninogenicus. Archs oral Biol., 19, 1231.

Holbrook, W. P., Ogston, S. A. AND Ross, P. W. 1978. A method for the isolation of Bacteroides melaninogenicus from the human mouth. J. med. Microbiol., 11, 203.

Holdeman, E. V., Cato, E. P. AND MoORE, W. E. C. (eds.) 1977. Anaerobe laboratory manual, 4th edition, Anaerobe Laboratory, Virginia Polytechnic Institute and State University, Blacksburg, Virginia.

Holdeman, L. V. AND Johnson, J. L. 1977. Bacteroides disiens sp. nov. and Bacteroides bivius sp. nov. from human clinical infections. Int. J. syst. Bact., $27,337$.

Hurley, R., Stanley, V. C., Leask, B. G. S. AND DE Louvois, J. 1974. Microflora of the vagina during pregnancy. In The normal microbial flora of man, edited by F. A. Skinner and J. G. Carr, Academic Press, London, p. 155.

KROPPENSTEDT, R. M. AND KUTZNER, H. J. 1976. Biochemical markers in the taxonomy of the Actinomycetales. Experientia, 32, 318.

LOESCHE, W. J. 1980. The role of anaerobes in periodontal disease. In Anaerobes and anaerobic infections. Symposium at XIIth International Congress of Microbiology, Munich, 1978, edited by G. Gottschalk, N. Pfennig and H. Werner, Fischer Verlag, Stuttgart, p. 61.

Loesche, W. J., Socransky, S. S. AND GibBons, R. J. 1964. Bacteroides oralis, proposed new species isolated from the oral cavity of man. J. Bact., 88, 1329.

MANSHEIM, B. J. AND Coleman, S. E. 1980. Immunochemical differences between oral and nonoral strains of Bacteroides asaccharolyticus. Infect. Immun., 27, 589.

Marrie, T. J., Harding, G. K. M. AND Ronald, A. R. 1978. Anaerobic and aerobic urethral flora in healthy females. J. clin. Microbiol., 8, 67. 
RusSEll, C. AND Melville, T. H. 1978. A review: bacteria in the human mouth. J. appl. Bact. 44, 163.

SCHLEIFER, K. H. AND KandLER, O. 1972. Peptidoglycan types of bacterial cell walls and their taxonomic implications. Bact. Rev., 36, 407.

Shah, H. N. AND HaRdie, J. M. 1979. Taxonomic studies on Bacteroides melaninogenicus, Bacteroides oralis, Bacteroides ruminicola and related organisms. Res. clin. For., 1; (3), 51.

Shah, H. N., Williams, R. A. D., Bowden, G. H. and Hardie, J. M. 1976. Comparison of the biochemical properties of Bacteroides melaninogenicus from human dental plaque and other sites. J. appl. Bact., 41, 473.

SLOTS, J. AND GeNCO, R. J. 1980. Bacteroides melaninogenicus subsp. macacae, a new subspecies from monkey periodontopathic indigenous microflora. Int. J. syst. Bact., 30, 82.

SOCRANSKY, S. S. AND GibBons, R. J. 1965. Required role of Bacteroides melaninogenicus in mixed anaerobic infections. J. inf. Dis., 115, 247.

SUNDQVIST, G. 1976. Bacteriological studies of necrotic dental pulps, Umeå University odontological dissertation no. 7, Umeå, Sweden.

Takazoe, I., TANakA, M. AND Homma, T. 1971. A pathogenic strain of Bacteroides melaninogenicus. Archs oral Biol., 16, 817.

VAN SteEnBergen, T. J. M., DE SoET, J. J. AND DE GraAfF, J. 1979. Genetic relationship between different subspecies of Bacteroides melaninogenicus. Antonie van Leeuwenhoek, 45, 513.

WERNER, H. 1972. Anaerobierdifferenzierung durch gaschromatographische Stoffwechselanalysen. Zentbl. Bakt. ParasitKde, I. Abt. Orig., A 220, 446.

WERNER, H. 1977. Anaerobes as normal flora: other sites. In Metronidazole-Proceedings of the International Metronidazole Conference, Montreal, Canada, edited by S. M. Finegold, Excerpta Medica, Int. Congress Series 438, Amsterdam, p. 229.

Werner, H., Lang, N., Krasemann, C. and Hammann, R. 1979. Häufigkeit und pathogenetische Bedeutung von Anaerobiern bei Kolpitis. Archs Gynec., 228, 620 .

WERNER, H. AND RINTELEN, G. 1968. Untersuchungen über die Konstanz der Kohlenhydratspaltung bei intestinalen Bacteroides-(Eggerthella-)Arten. Zentbl. Bakt. ParasitKde, I. Abt. Orig., 208, 521.

Williams, R. A. D., Bowden, G. H., Hardie, J. M. and Shah, H. 1975. Biochemical properties of Bacteroides melaninogenicus subspecies. Int. J. syst. Bact., 25, 298. 